\title{
A long-term, spatially replicated experimental test of the effect of marine reserves on local fish yields
}

\author{
Angel C. Alcala, Garry R. Russ, Aileen P. Maypa, and Hilconida P. Calumpong
}

\begin{abstract}
Do no-take marine reserves affect fishery yields? Manipulations of reserve status, and yield estimates, were made at two Philippine islands over two decades. Twenty-five percent and ten percent, respectively, of the coral reefs at Sumilon and Apo islands were made no-take reserves in 1974 and 1982. Biomass of target fish increased inside the no-take reserves 3- to 4.5-fold over 9-18 years. Biomass did not increase outside each reserve. Protection of the Sumilon reserve ceased in 1984. Biomass of targeted fish in the reserve and trap and gillnet catches of these fish declined by $42.7 \%$ and $40 \%$, respectively, by 1985. The reserve was reprotected from 1987 to 1991 and from 1995 to 2001. Fish biomass increased in the reserve by $27.2 \%$. Trap and gillnet catches outside the reserve increased $26.9 \%$ by 2001. The Apo reserve was protected from 1982 to 2001. Total catch of major fish families was significantly higher after (1985-2001) than before (1981) reserve establishment at Apo, increasing 41.3\% between 1981 and $1998-2001$. These experiments, plus spillover evidence, suggest that marine reserves may help maintain, or even enhance, local fishery yields in the long-term.
\end{abstract}

\begin{abstract}
Résumé : Est-ce que les réserves marines sans pêche affectent le rendement des pêches? Des manipulations du statut de réserves et des estimations des rendements ont été faites près de deux îles des Philippines au cours de deux décennies. Respectivement $25 \%$ et $10 \%$ des récifs coralliens près des îles Sumilon et Apo ont été déclarés des réserves sans pêche en 1974 et en 1982. La biomasse des poissons ciblés a augmenté d'un facteur de 3-4,5 fois dans les réserves sans pêche au cours d'une période de 9-18 ans. La biomasse n'a pas augmenté à l'extérieur de ces deux réserves. La protection de la réserve de Sumilon a cessé en 1984. En 1985 dans la réserve, la biomasse des poissons ciblés et les captures de ces poissons dans des pièges et les filets maillants avaient diminué respectivement de 42,7\% et de 40 \%. La réserve a bénéficié de nouveau de protection en 1987-1991 et en 1995-2001. La biomasse des poissons dans la réserve a augmenté de 27,2 \%. En 2001, les captures au piège et au filet maillant hors de la réserve avaient augmenté de $26,9 \%$. Les captures totales de poissons des familles importantes étaient plus fortes après (1985-2001) qu'avant (1981) l'établissement de la réserve à Apo et ont augmenté de 41,3 \% entre 1981 et 1998-2001. Ces expériences, plus des évidences de l'existence de débordements de populations, indiquent que les réserves marines peuvent servir à maintenir et même à améliorer à long terme les rendements des pêches locales.
\end{abstract}

[Traduit par la Rédaction]

\section{Introduction}

No-take marine reserves are areas of the marine environment in which all forms of extraction by humans, primarily fisheries, are banned permanently (Allison et al. 1998; Roberts and Hawkins 2000; Gell and Roberts 2002). Marine re-

Received 27 August 2003. Accepted 27 July 2004. Published on the NRC Research Press Web site at http://cjfas.nrc.ca on 4 March 2005.

J17716

A.C. Alcala and A.P. Maypa. Silliman University Angelo King Center for Research and Environmental Management, Silliman University, Dumaguete City, 6200, Philippines.

G.R. Russ. ${ }^{1}$ School of Marine Biology and Aquaculture, James Cook University, Townsville, Queensland, 4811, Australia.

H.P. Calumpong. Silliman University Marine Laboratory, Silliman University, Dumaguete City, 6200, Philippines.

${ }^{1}$ Corresponding author (e-mail: garry.russ@jcu.edu.au). serves are often promoted as a mechanism to address problems such as loss of marine biodiversity (Dayton et al. 2000; Roberts and Hawkins 2000; Jackson et al. 2001) and alteration of trophic structure of marine ecosystems (Pauly et al. 1998; Jackson et al. 2001). They are also often promoted as one tool to help manage fisheries (Gell and Roberts 2002; Russ 2002; Gerber et al. 2003). In addition, marine reserves have other important economic and social benefits, such as enhancing tourism (Roberts and Hawkins 2000).

A major expectation of no-take marine reserves as fisheries management tools is that they will, in the long-term, allow buildup of spawning stock biomass within them and help maintain, or even enhance, fishery yields outside them (Alcala and Russ 1990; Gell and Roberts 2002). Marine reserves are expected to sustain fisheries external to them by becoming net exporters of adults (the spillover effect) and net exporters of propagules (the recruitment effect) (Russ 2002). The spillover effect is generally expected to operate locally on spatial scales of hundreds of metres to kilometres for many organisms targeted by fisheries (McClanahan and 
Mangi 2000; Roberts et al. 2001; Russ 2002). The recruitment effect is expected to operate on the scales of dispersal of pelagic larvae, perhaps tens of kilometres (Palumbi 2001; James et al. 2002; Gaines et al. 2003). Local fishery benefits from spillover (net export of adults) and possible localized export of propagules will likely generate support from fishing communities for marine reserves (Russ and Alcala 1996; Roberts et al. 2001; Gell and Roberts 2002). However, longterm experimental tests of the effects of marine reserves on local fishery yields are rare.

There is a rapidly increasing number of empirical and theoretical studies suggesting that marine reserves can affect fisheries in a positive way beyond their boundaries (Gell and Roberts 2002). The majority of this evidence consists of studies demonstrating changes in abundance of targeted species or fishing patterns outside the boundaries of no-take reserves. Such changes include higher abundance (Rakitin and Kramer 1996; Russ and Alcala 1996), fisheries catch per unit effort (CPUE) (Rakitin and Kramer 1996; McClanahan and Kaunda-Arara 1996; McClanahan and Mangi 2000), and fishing effort (Murawski et al. 2000; Kelly et al. 2002) close to, but not farther from, reserve boundaries. Other studies have demonstrated development of higher CPUE over time outside reserves (McClanahan and Kaunda-Arara 1996; Roberts et al. 2001; Maypa et al. 2002). However, there are few studies that examine the key question of the effect of no-take reserves on absolute yields of the fishery (Alcala and Russ 1990; McClanahan and Kaunda-Arara 1996; Roberts et al. 2001).

A common expectation of fishers is a loss of fisheries yield following reserve establishment, approximately equivalent to that caught previously in the closed area (Roberts and Hawkins 2000). This assumes that total fishing effort stays the same after implementation of the reserve. Some fishers even suggest that total fishery yields may decline, since the remaining fishing effort is concentrated on the stocks outside the reserve, causing overfishing. However, if biomass of targeted fish can build up over time inside the reserve, leading to spillover, and perhaps localized export of propagules, the total loss of fisheries yield may not equal what was caught previously in the area before it became a reserve. Furthermore, fishing patterns may change because of other effects of reserves, for example increased income to the fishing community generated from tourism by the reserve (e.g., Russ et al. 2004). In such cases, absolute yields may stay stable (Maypa et al. 2002) or even improve (Russ et al. 2004). A neutral or positive effect of a reserve on absolute yield may occur provided that sufficient time is available to allow substantial recovery of fish stocks both inside and outside the reserve.

The effect of establishment of no-take reserves on fisheries yields, be it negative, neutral, or positive, will clearly be dependent on the spatial and temporal scales of study. At the spatial scale of the entire stock, loss of catch owing to loss of fishing area has to be balanced against any gains owing to the spillover and recruitment effects. Clearly, the balance between loss and gain of yield will vary over time, as biomass builds up over time in the reserves relative to the fished areas. At the scale of a local fishery, it has been assumed until recently that loss of catch owing to loss of fishing area had to be balanced against any gains owing only to spillover.
However, recent studies of the potential for limited larval dispersal and "self-recruitment" (e.g., Jones et al. 1999; Swearer et al. 1999; James et al. 2002) have led to the possibility that reserves may affect local fishery yields by both spillover and the recruitment effect. Gell and Roberts (2002) recently suggested that abundance and catch rates outside reserves in St. Lucia (Roberts et al. 2001), the Egyptian Red Sea (Galal et al. 2002), and the Philippines (Maypa et al. 2002) have improved so markedly that the local fisheries may have been affected by larval export as well as spillover.

In this study, we investigate the effects of experimental manipulations of marine reserve status on local fishery yields at two small islands in the Philippines, Sumilon and Apo. These studies have been carried out over periods of 22 and 20 years, respectively. We ask the question does establishment of a no-take marine reserve have a negative, neutral, or positive effect on local fishery yield in the long term?

\section{Materials and methods}

\section{Study sites}

The study was carried out at two islands in the central Philippines (Fig. 1), Sumilon Island southeast of Cebu $\left(9^{\circ} 21^{\prime} \mathrm{N}\right.$, $\left.123^{\circ} 23^{\prime} \mathrm{E}\right)$ and Apo Island southeast of Negros $\left(9^{\circ} 4^{\prime} \mathrm{N}\right.$, $\left.123^{\circ} 16^{\prime} \mathrm{E}\right)$. Sumilon Island had a no-take marine reserve established on its western side in December 1974. Apo Island had a no-take marine reserve established on its southeastern side in late 1982. Sumilon Island is a coralline island of $0.23 \mathrm{~km}^{2}$ surrounded by a fringing coral reef of $0.5 \mathrm{~km}^{2}$ to the $40-\mathrm{m}$ isobath. Apo Island is a mainland island of $0.7 \mathrm{~km}^{2}$ surrounded by $1.06 \mathrm{~km}^{2}$ of fringing coral reef to the $60-\mathrm{m}$ isobath $\left(0.7 \mathrm{~km}^{2}\right.$ to the $20-\mathrm{m}$ isobath).

The Sumilon reserve is a $0.75-\mathrm{km}$ section (approximately $25 \%$ of the coral reef area) of the western side of the island (Fig. 1). The area of the reserve to $500 \mathrm{~m}$ from shore is 37.5 ha. The Apo reserve is a $0.45-\mathrm{km}$ section (approximately $10 \%$ of the coral reef area) of the southeastern side of the island (Fig. 1). The management histories of the Sumilon and Apo reserves and the fished portions of these two islands are provided in Table 1. The Sumilon reserve has had a complex history of management over the period 1974-2001 (Table 1) (Russ and Alcala 1999). The no-take status of the Apo marine reserve has been maintained successfully from 1982 to 2001 (Table 1) (Russ and Alcala 1999). Decisions to apply no-take status at each island and to remove it at Sumilon were taken by the local municipalities. In all cases, these decisions were taken because local leaders perceived that the actions would benefit the local communities. For example, no-take status was applied at Sumilon (1974 and 1987) and Apo (1982) in the hope of maintaining fisheries and enhancing tourism at the islands. No-take status was removed at Sumilon (1984) when new mayors were elected that did not support the reserve concept (Russ and Alcala 1999). Thus, the management histories were not designed as scientific experiments. However, they are natural experiments in the sense that management actions did result in real changes to no-take status.

\section{Method of visual census}

Estimates of fish biomass were made visually at the reserve and a nonreserve (fished) site at each island in Decem- 
Fig. 1. Map showing the location of Sumilon and Apo islands, central Philippines, and the location of the unfished reserve areas (shaded) and the fished nonreserve areas at each island. The positions of the six $50 \mathrm{~m} \times 20 \mathrm{~m}$ replicate underwater visual census plots (solid rectangles) surveyed at each sampling site and time are shown.

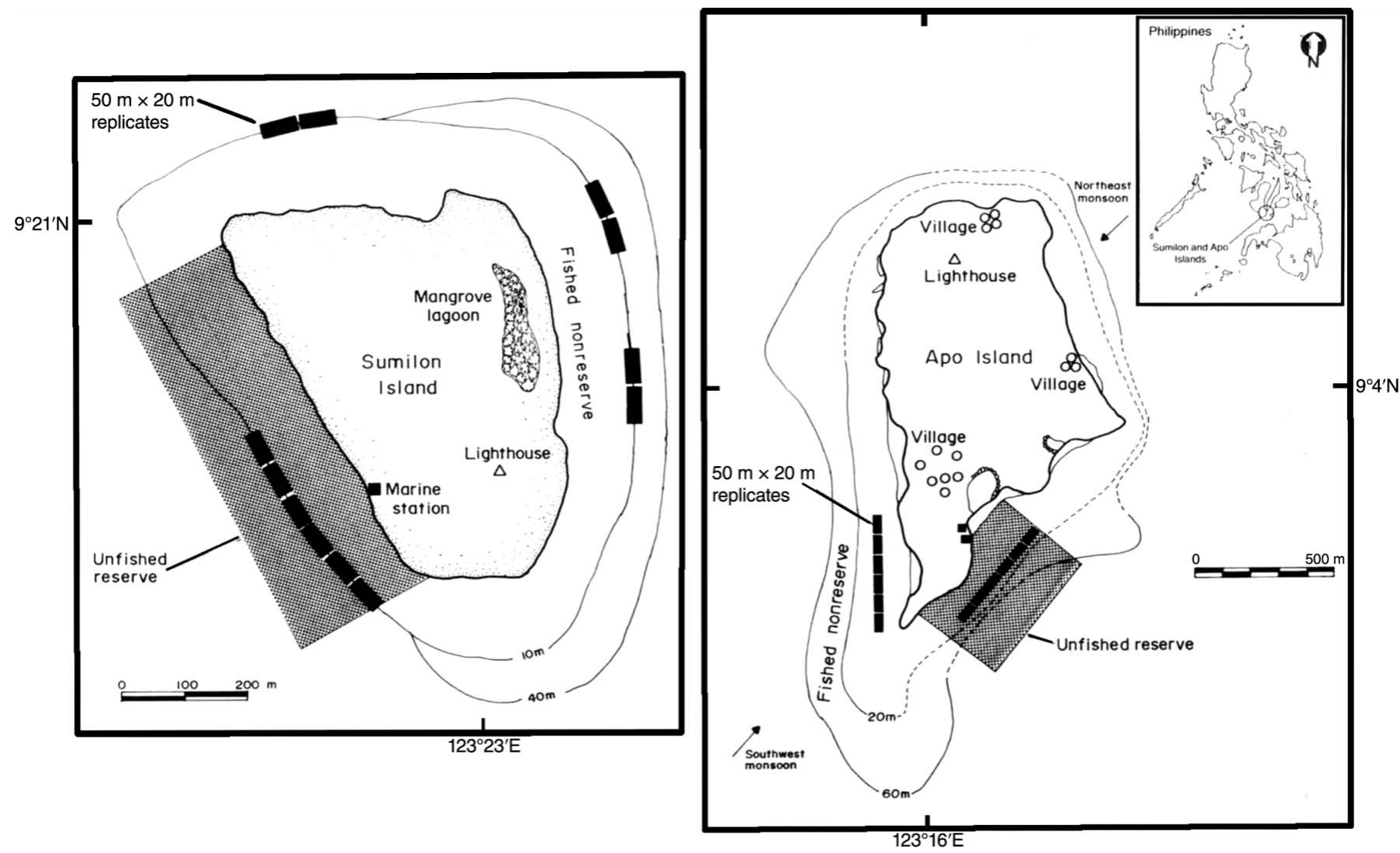

Table 1. History of protection status for the two no-take reserves and control (fished) portions (nonreserves) at Sumilon and Apo islands over the period 1974-2001.

\begin{tabular}{|c|c|c|c|}
\hline Site & Time period & Protection status & Comments \\
\hline SR & $\begin{array}{r}\text { Dec. } 1974- \\
\text { May } 1984\end{array}$ & No-take for 9.5 years & $\begin{array}{l}\text { No-take status established under a municipal law } \\
\text { and maintained by caretaker }\end{array}$ \\
\hline SR & 1984-1986 & $\begin{array}{l}\text { Reserve pulse-fished for } \\
\text { about } 2.5 \text { years }\end{array}$ & $\begin{array}{l}\text { Caused by election of new municipal mayors. } \\
\text { Fishing techniques included explosives and } \\
\text { drive nets ("muro-ami") }\end{array}$ \\
\hline SR & $1987-1991$ & No-take for 5 years & No-take status reestablished by local municipality \\
\hline SR & 1992-1994 & Reserve opened to fishing & $\begin{array}{l}\sim 100 \text { municipal fishers using traps, hook and line, } \\
\text { gill net, and spear }\end{array}$ \\
\hline SR & 1995-2001 & Fishing restricted & All fishing except hook and line banned \\
\hline SNR & $1974-1987$ & Open to fishing & $\begin{array}{l}\sim 100 \text { municipal fishers using traps, hook and line, } \\
\text { gill net, and spear }\end{array}$ \\
\hline SNR & $1987-1991$ & No-take for 5 years & No-take status established by local municipality \\
\hline SNR & 1992-2001 & Open to fishing & $\begin{array}{l}\text { 100 municipal fishers using traps, hook and line, } \\
\text { gill net, and spear }\end{array}$ \\
\hline AR & $\begin{array}{l}\text { Dec. } 1982- \\
\text { Dec. } 2001\end{array}$ & No-take for 19 years & $\begin{array}{l}\text { No-take status established and maintained by local } \\
\text { community ( } \sim 500 \text { residents })\end{array}$ \\
\hline ANR & $1982-2001$ & Open to fishing & $\begin{array}{l}\text { Nonreserve area fished by } \sim 200 \text { fishers using } \\
\text { traps, hook and line, gill net, and spear }\end{array}$ \\
\hline AR, ANR & Nov. 1986 & Marine management plan & $\begin{array}{l}\text { Marine management plan established under munic- } \\
\text { ipal law. This banned explosives, drive nets, } \\
\text { small-mesh nets, poisons from the entire island, } \\
\text { and banned fishing by nonresidents }\end{array}$ \\
\hline
\end{tabular}

Note: S, Sumilon Island; A, Apo Island; R, reserve; NR, nonreserve. Histories derived from Russ and Alcala (1999) and White et al. (2002). 
ber or November of each year from 1983 to 2001 except for 1984, 1986-1987, and 1996. Five families of reef fish (Acanthuridae, Carangidae, Lutjanidae, Lethrinidae, and Caesionidae) were censused. These families made up $92.3 \%$ and $82.8 \%$ of the fisheries yield at Sumilon and Apo, respectively (Alcala 1981; Alcala and Russ 1990; Maypa et al. 2002). The method of underwater visual census has been published elsewhere (Russ and Alcala 1998). Six 1000-m² replicate areas of reef slope were censused in the reserves (2-17 m depth) and nonreserves (9-17 m depth) on each sampling occasion. The observer (G.R.R.), the method of underwater visual census, and the position of the replicates were the same from 1983 to 2001 (Fig. 1) (except that some replicate areas at the Apo nonreserve site differed between 1983 and all other times). The abundances of small species of Acanthuridae (Ctenochaetus, small Acanthurus, and small Naso) and all species of Caesionidae were estimated cumulatively in $\log 4$ abundance categories in a census area. These categories were as follows: category $1=1$ fish, category $2=2-4$ fish, category $3=5-16$ fish, category $4=17-$ 64 fish, category $5=65-256$ fish, category $6=257-1024$ fish, and category $7=1025-4096$ fish. Use of these abundance categories is likely to compromise accuracy of estimates for speed of surveys. However, any potential bias in biomass estimates will be likely consistent across times and sites. Simultaneously, actual counts and estimates of total length $( \pm 5 \mathrm{~cm})$ of large Acanthuridae (large Acanthurus and large Naso) and all species of Carangidae, Lutjanidae, and Lethrinidae were made. Juveniles $(<10 \mathrm{~cm})$ were not counted. An estimate of biomass for those species for which density and size structure data were available was constructed using published length-weight relationships for the species or closely related species (Froese and Pauly 1997). Length estimates were not made for Caesionidae and individuals of small species of Acanthuridae. These species thus lacked size structure data. An estimate of average length of a fish in the genus was made and converted to an average weight from published length-weight relationships (Froese and Pauly 1997). Abundances of Caesionidae and the small species of Acanthuridae were converted to approximate estimates of density by using midpoints of abundance categories. Density and average weight estimates were then used to estimate biomass per unit area. A long-term and substantial decline in abundance of Caesionidae occurred in the Apo Reserve beginning around 1992, possibly associated with reduced recruitment (Russ and Alcala 1998). Thus, we express trends in biomass and catch at Apo with and without this family.

\section{Estimates of annual catch}

Annual trap and gillnet catch of five families (Acanthuridae, Carangidae, Lutjanidae, Lethrinidae, and Caesionidae) was estimated in five separate years at Sumilon Island (Table 2). The years 1979, 1980, and 1983 were years of relatively long-term reserve protection $(6,7$, and 10 years) at Sumilon. In 1985-1986, the reserve had been pulse-fished for almost 2 years, and fish biomass in the reserve had been reduced significantly (Alcala and Russ 1990). By 2001, the reserve had been reprotected to varying degrees since 1987, and biomass had shown some degree of recovery. Annual catch of trap, gill net, hook and line, and spear of the same five families was estimated at Apo once before (1980-1981: Alcala and Luchavez 1981) and five times after (1985-1986, 1986, 1997-1998, 2000, and 2001: White and Savina 1987; Bellwood 1988; Maypa et al. 2002) reserve establishment (Table 2). Catch data at Sumilon and in the early studies at Apo were recorded at the family level. Although each family contains many targeted species, such pooling within families is justified, since life histories are generally consistent within each family, with the possible exception of the Acanthuridae.

\section{Data analysis}

Statistical comparisons of biomass of fish at the reserve and nonreserve sites over the 14 times were made separately for each island using univariate, repeated-measures ANOVA. The three factors in these analyses were reserve (two levels), plots (six levels) nested within each reserve and nonreserve site (a random factor), and the repeated measure time with 14 levels. The data were examined for homogeneity of variance (Cochran's test at $p<0.05$ ) (Underwood 1981), skewness and outliers (Box plots), normality, and correlations between means and variances. Data were transformed $\left(\log _{10}(x)\right)$. We used Greenhouse-Geisser adjusted $p$ values for the reserve-time interaction (Statsoft, Inc. 1995). Temporal trends in biomass at reserve and nonreserve sites at each island were examined by linear regression. Biomass was plotted against years of reserve protection for both the Sumilon and Apo reserves. One of the 14 sampling times (1992) at the Sumilon reserve was omitted from these regressions. In 1992, the Sumilon reserve had been open to fishing for 1 year (and thus, years of protection was assigned a value of -1 ) but had built up considerable fish biomass during 5 years of protection from 1987 to 1991 (Table 1). Fish biomass in the nonreserve sites was plotted against years of reserve protection at the island by simply plotting the nonreserve biomass for the same year as that for the biomass estimate in the reserve for any given duration of protection. Four of the 14 sampling times (1988, 1990, 1991, and 1992) at the Sumilon nonreserve were omitted from these regressions. During this time, the Sumilon nonreserve was protected from fishing (1987-1991) or had been open to fishing for a short time following a long period of no fishing (Table 1).

A one-sample $t$ test was used to compare trap plus gillnet catch of the five families at Sumilon in 1985 (after the reserve biomass was fished down) with that over the period 1979-1983 (6-10 years of reserve protection). The same test was used to compare trap plus gillnet catch of the five families at Sumilon in 2001 (after the reserve biomass had recovered somewhat) with that over the period 1979-1983 (610 years of reserve protection). A one-sample $t$ test was used to compare trap, gillnet, hook and line, and spear catch of four families at Apo (minus Caesionidae) in 1980-1981 (before reserve establishment) with that over the period 19852001 (3-18 years of reserve protection). Biomasses of the five families of reef fish in the Sumilon reserve were compared between 1983 (protected for 10 years) and 1985 (fished down) and between 1985 (fished down) and 2001 (some level of recovery) with $t$ tests. Changes in catch with duration of reserve protection at each island were examined by linear regression. 


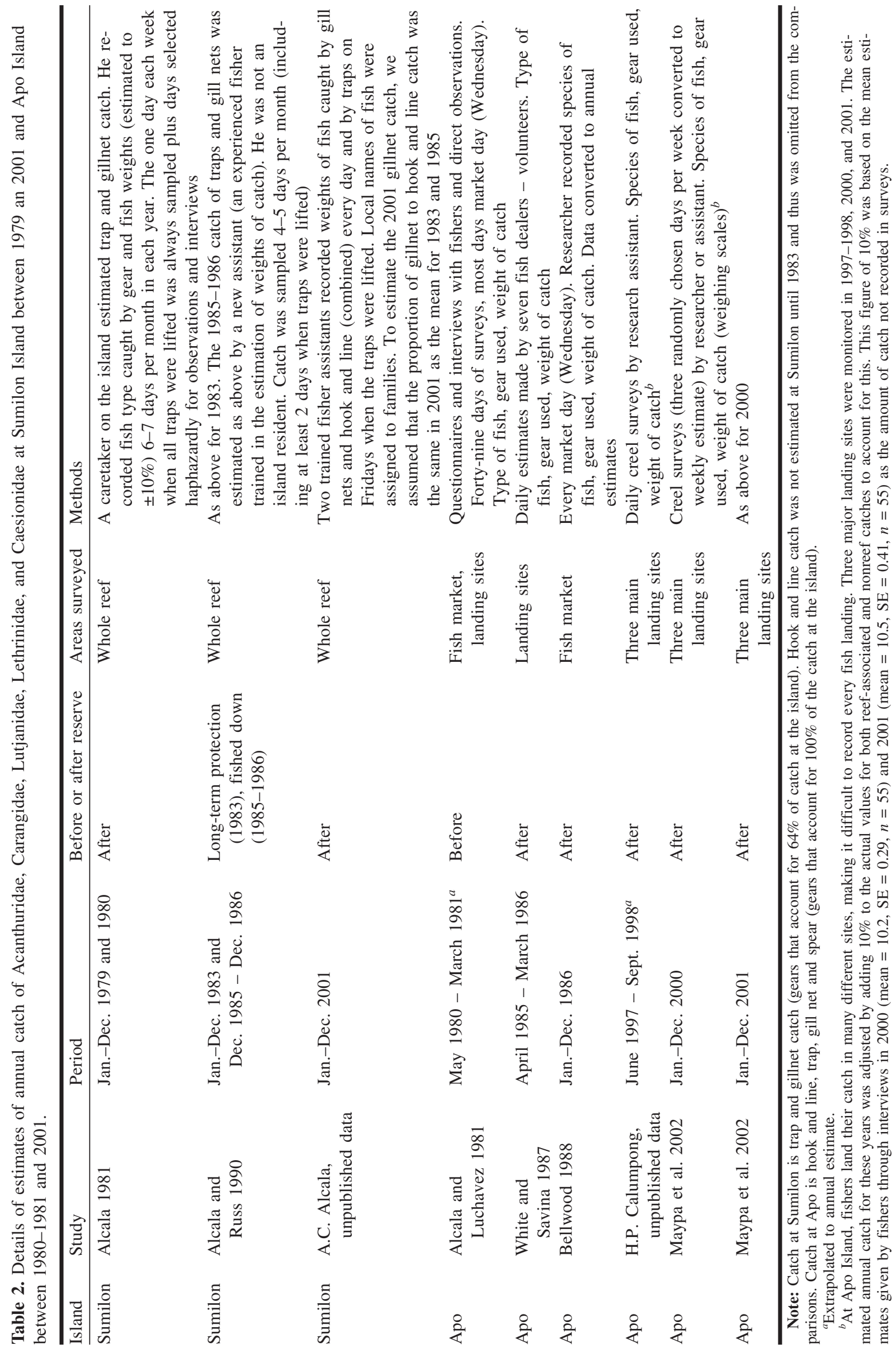


Fig. 2. Underwater visual census estimates of biomass of five families of reef fish (Acanthuridae, Carangidae, Lutjanidae, Lethrinidae, and Caesionidae) in reserve and nonreserve sites (1983-2001) and estimates of total annual catch of these families (1979-2001) plotted against years of reserve protection at Sumilon and Apo islands. Negative years of protection at the Sumilon reserve indicate years open to fishing. Open data points are biomass estimates when the site was open to fishing or catch estimate at the island in the absence of reserve. Solid data points are biomass estimates when the site was closed to fishing or catch estimate at the island in the presence of reserve. Shaded data points are biomass or catch estimates when the Sumilon reserve was partially closed to fishing. Error bars for biomass estimates are SEs. $(a-c)$ nonreserve biomass, reserve biomass, and catch at Sumilon; $(d-f)$ nonreserve biomass, reserve biomass, and catch at Apo; $(g-i)$ nonreserve biomass, reserve biomass, and catch at Apo with Caesionidae omitted.
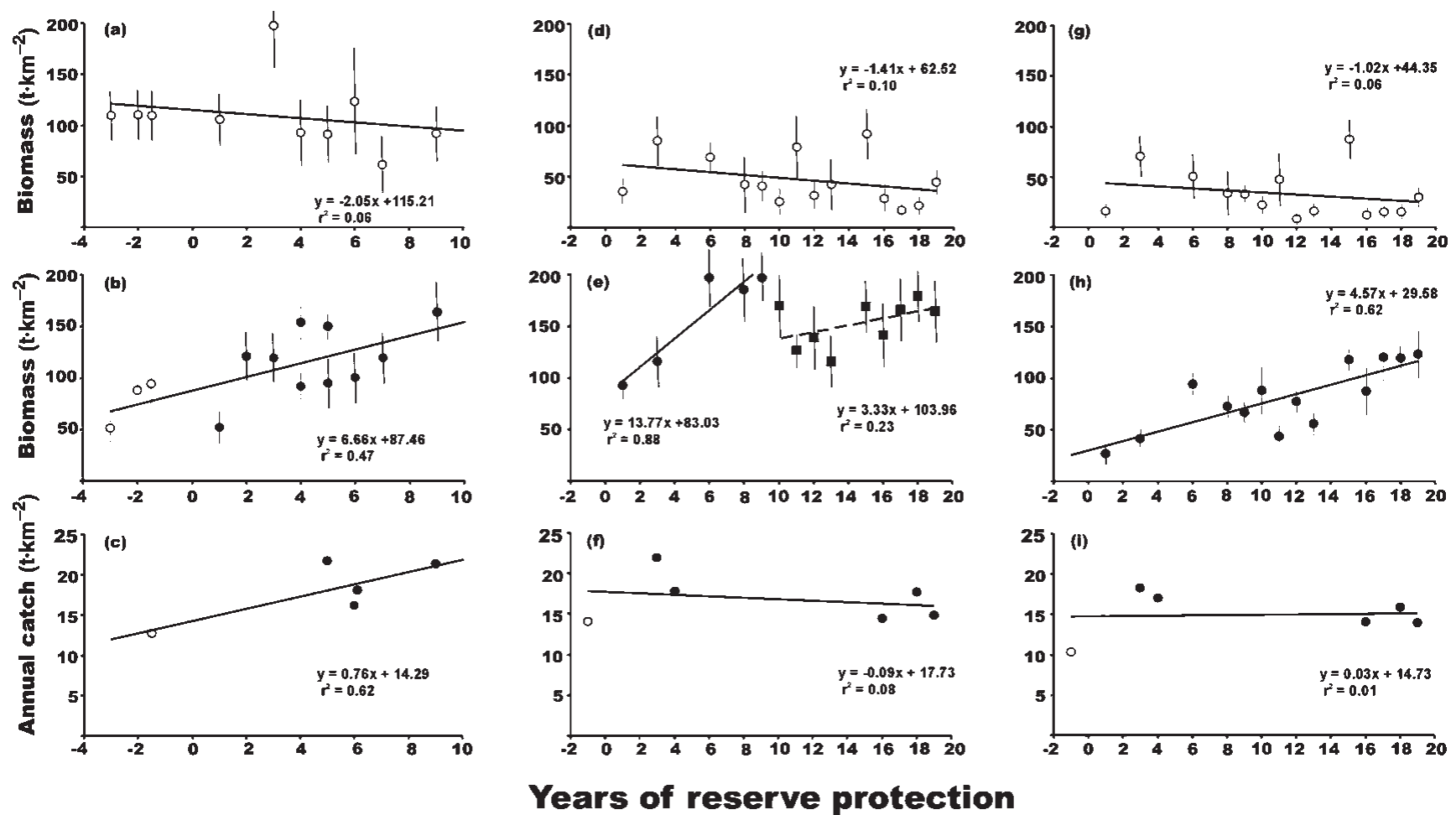

\section{Results}

The biomass of targeted fish (Acanthuridae, Carangidae, Lutjanidae, Lethrinidae, and Caesionidae) had a significant positive correlation with years of reserve protection inside $\left(F_{[1,11]}=9.77, p<0.01\right)$ but not outside $\left(F_{[1,8]}=0.48, p>\right.$ 0.05 ) the Sumilon reserve (Figs. $2 a$ and $2 b$ ) (repeatedmeasures ANOVA: protection-time interaction, $F_{[13,130]}=$ $3.30, p<0.001$ ) (Table 3). The biomass of targeted fish increased by a factor of 3.1 between 1 and 9 years of reserve protection at Sumilon (Fig. 2b). Fish biomass was relatively high and variable in abundance in the Sumilon nonreserve (Fig. 2a). However, a clear difference in the fish biomass between reserve and nonreserve sites was apparent at around 6 years of reserve protection (Figs. $2 a$ and $2 b$ ). The biomass of the same five fish families had a significant positive correlation with years of reserve protection inside the Apo reserve for the first 9 years of protection $\left(F_{[1,3]}=21.02, p<\right.$ $0.05)$ (Fig. $2 e)$ but not for the next 9 years $\left(F_{[1,7]}=2.10, p>\right.$ 0.05 ) (Fig. 2e). There was no significant correlation between years of reserve protection and biomass of these five families in the Apo nonreserve $\left(F_{[1,12]}=1.34, p>0.05\right)$ (Fig. $2 d$ ). The biomass of the same five fish families minus Caesionidae did have a significant positive correlation with years of reserve protection inside $\left(F_{[1,12]}=19.88, p<0.001\right)$ but not outside $\left(F_{[1,12]}=0.72, p>0.05\right)$ the Apo reserve over the full 18 years of the study (Figs. $2 g$ and $2 h$ ) (repeated- measures ANOVA: protection-time interaction, $F_{[13,130]}=$ $4.56, p<0.001$ ) (Table 3). The biomass of targeted fish increased by a factor of 4.6 between 1 and 19 years of reserve protection at Apo (Fig. 2h). A clear difference in the fish biomass between reserve and nonreserve sites was apparent at around 6 years of reserve protection (Figs. $2 g$ and $2 h$ ). The results at both islands are consistent with the hypothesis that the removal of fishing caused the increase in fish biomass in the reserves.

The correlations between biomass of the five families and reserve protection reported for Sumilon Island (Fig. 2) resulted from a complex history of management at the island (Russ and Alcala 1999). The effects of this history on the fish biomass in the Sumilon reserve and nonreserve for the period 1983-2001 are also shown (Fig. 3). In the Sumilon reserve, fish biomass declined by $42.7 \%$ between 1983 and 1985 during an intense fishing event (Fig. 3a; Table 1). Biomass rose in the reserve $59.6 \%$ by 1991 after 5 years of protection (Fig. 3a; Table 1) and then fell $65.8 \%$ by 1994 after the reserve was again opened to fishing (Fig. $3 a$; Table 1). When all forms of fishing except hook and line were banned in the reserve in 1995 , biomass rose by $132 \%$ by 2001 (Fig. 3a; Table 1). Biomass in the reserve rose by $26.7 \%$ between 1985 and 2001 during this period of intermittent protection (Fig. 3a; Table 1). Note also that biomass estimates in the reserve under partial protection (all fishing gears banned except hook and line) (shaded data points in Fig. 2b) 
Table 3. Results of repeated-measures ANOVA of fish biomass in reserve and nonreserve sites at Sumilon and Apo islands over the period 1983-2001.

\begin{tabular}{llrrcl}
\hline \multirow{2}{*}{ Island } & Source of & \multicolumn{5}{c}{ Mean } \\
Sumilon & Rariation & df & square & $F$ ratio & $p$ \\
& Reserve & 1 & 0.042 & 0.08 & $\mathrm{~ns}$ \\
& Time & 13 & 0.279 & 3.93 & $<0.001$ \\
& Reserve-time & 13 & 0.235 & 3.30 & $<0.001$ \\
& Plots (reserve) & 10 & 0.555 & 7.82 & $<0.001$ \\
& Residual & 130 & 0.071 & & \\
Apo & Total & 167 & 1.182 & & \\
& Reserve & 1 & 11.124 & 40.42 & $<0.001$ \\
& Time & 13 & 0.433 & 5.73 & $<0.001$ \\
& Reserve-time & 13 & 0.344 & 4.56 & $<0.001$ \\
& Plots (reserve) & 10 & 0.275 & 3.62 & $<0.001$ \\
& Residual & 130 & 0.076 & & \\
& Total & 167 & & & \\
\hline
\end{tabular}

Note: Biomass estimates were made for five families of reef fish at Sumilon (Acanthuridae, Carangidae, Lutjanidae, Lethrinidae, and Caesionidae) and four families at Apo (same as Sumilon minus Caesionidae). ns, $p>0.05$

were always less than those for full protection (solid data points in Fig. $2 b$ ). Biomass in the Sumilon nonreserve was generally stable during periods open to fishing (Fig. 3b; Table 1). Biomass in the nonreserve rose by $89.8 \%$ between 1985 and 1991 during 5 years of protection ((Fig. 3b; Table 1). Biomass declined by $70.5 \%$ between 1991 and 2001 when opened to fishing (Fig. 3b; Table 1).

The $42.7 \%$ decline in biomass of the five families of fish in the Sumilon reserve between 1983 and $1985\left(t_{5 \mathrm{df}}=2.73\right.$, $p<0.05$ ) (Fig. $4 a$ ) coincided with a $40 \%$ decline in catch of traps and gill nets outside the reserve over the same period $\left(t_{2 \mathrm{df}}=6.70, p<0.01\right)$ (Fig. $\left.4 a\right)$. The Sumilon reserve was then reprotected to varying degrees from fully protected (1987-1991) to all fishing gears but hook and line banned (1995-2001) (Fig. 3a; Table 1). The 27.2\% increase in fish biomass inside the Sumilon reserve between 1985 and 2001 $\left(t_{5 \mathrm{df}}=0.38, p>0.05\right)$ (Fig. $\left.4 a\right)$ coincided with a $26.9 \%$ increase in trap and gillnet catch outside the reserve over the same period $\left(t_{5 \mathrm{df}}=0.38, p>0.05\right)$ (Fig. $4 a$ ). Total catch of targeted fish (minus Caesionidae) was significantly higher (by 52.7\%) after (1985-2001) than before (1981) reserve establishment at Apo Island $\left(t_{4 \mathrm{df}}=6.60, p<0.01\right)$ (Fig. $\left.4 b\right)$. A more conservative interpretation would be a comparison of the total catch at Apo before the reserve was established (1981) with that when the biomass in the reserve was very high (1998-2001). This comparison suggests a $41.3 \%$ increase in catch of these fish (Fig. 4b). The fish biomass increased significantly (by a factor of 4.6 over 18 years) inside the Apo reserve (linear regression, $F_{[1,12[}=19.88, p<0.001$ ) (Fig. 2h).

The relationship between biomass in the reserve and annual catch varied between the two islands (Fig. 2). At Sumilon, there were strong positive correlations between targeted fish biomass in the reserve $\left(F_{[1,11]}=9.77, p<0.01\right)$ (Fig. $2 b)$ and catch outside the reserve $\left(F_{[1,3]}=4.93, p=\right.$ 0.11 ) (Fig. $2 c$ ) with years of reserve protection, although the latter relationship was not statistically significant owing to the low number of degrees of freedom of the test. At Apo, there was a strong positive relationship between targeted fish biomass in the reserve with years of reserve protection $\left(F_{[1,12]}=19.88, p<0.001\right)$ (Fig. $\left.2 h\right)$ but no significant relationship between catch outside the reserve and years of reserve protection $\left(F_{[1,4]}=0.21, p>0.05\right)$ (Fig. $\left.2 i\right)$.

\section{Discussion}

We have demonstrated that closure to fishing of $10 \%-$ $25 \%$ of fishing area of two small islands in the Philippines did not reduce total fishery catch at the islands in the long term (two decades). On the contrary, the experimental evidence suggests that the total catch was sustained, or even enhanced, in the long term. These results are particularly significant, given that municipal (subsistence) fishing is such a major human activity at each island.

The prerequisite for beneficial fishery effects of no-take marine reserves beyond their boundaries is that biomass of targeted fish increases substantially over time inside relative to outside the reserves. Such patterns were clear at both Sumilon and Apo islands. Biomass was greater in reserve than fished areas after about 6 years of effective no-take protection at each island, and these differences became larger with increased duration of protection up to 19 years. The rates of biomass buildup inside the reserves were generally consistent with expectations based on life history characteristics of the fish (Russ and Alcala 1998). Large predators (Lutjanidae, Lethrinidae, and Carangidae) and many Acanthuridae (surgeonfish) are long-lived, often with low rates of natural mortality and recruitment. Such characteristics would suggest that recovery rates would be gradual over two decades, as observed. On the other hand, Caesionidae are generally short-lived, with high rates of natural mortality and recruitment (Russ and Alcala 1998).

In addition to long-term demonstrations of biomass buildup inside reserves, we have clear evidence, at least for Apo Island, of mechanisms by which the no-take reserve may have influenced the local fishery (Russ and Alcala 1996; Russ et al. 2003, 2004). These mechanisms are spillover from the reserve (Russ and Alcala 1996; Russ et al. 2003) and a general improvement in the reef resources associated with the implementation of a marine management plan in 1986, which included establishment of the no-take reserve (Russ et al. 2004).

This study expands and combines our previous studies of these two reserves and their adjacent fisheries. For the first time, we show the dynamic response of biomass of targeted fish at the Sumilon reserve and nonreserve to changes in fishing levels over the period 1983-2001. The observations that both reserve biomass and catch at Sumilon were initially high after almost a decade of protection (1983), declined by 1985-1986 after intense fishing, and then recovered again by 2001 are novel. At Apo, both initial biomass and prereserve catch were low at the beginning of the study. Reserve biomass increased substantially over almost two decades of protection, and catch was higher or at least remained relatively stable. Combined, these studies constitute a unique, spatially replicated natural experiment. 
Fig. 3. Underwater visual census estimates of biomass of five families of reef fish (Acanthuridae, Carangidae, Lutjanidae, Lethrinidae, and Caesionidae) in $(a)$ reserve and $(b)$ nonreserve sites at Sumilon Island from 1983 to 2001. Arrows show the change in fishing status over time. Error bars are SEs.
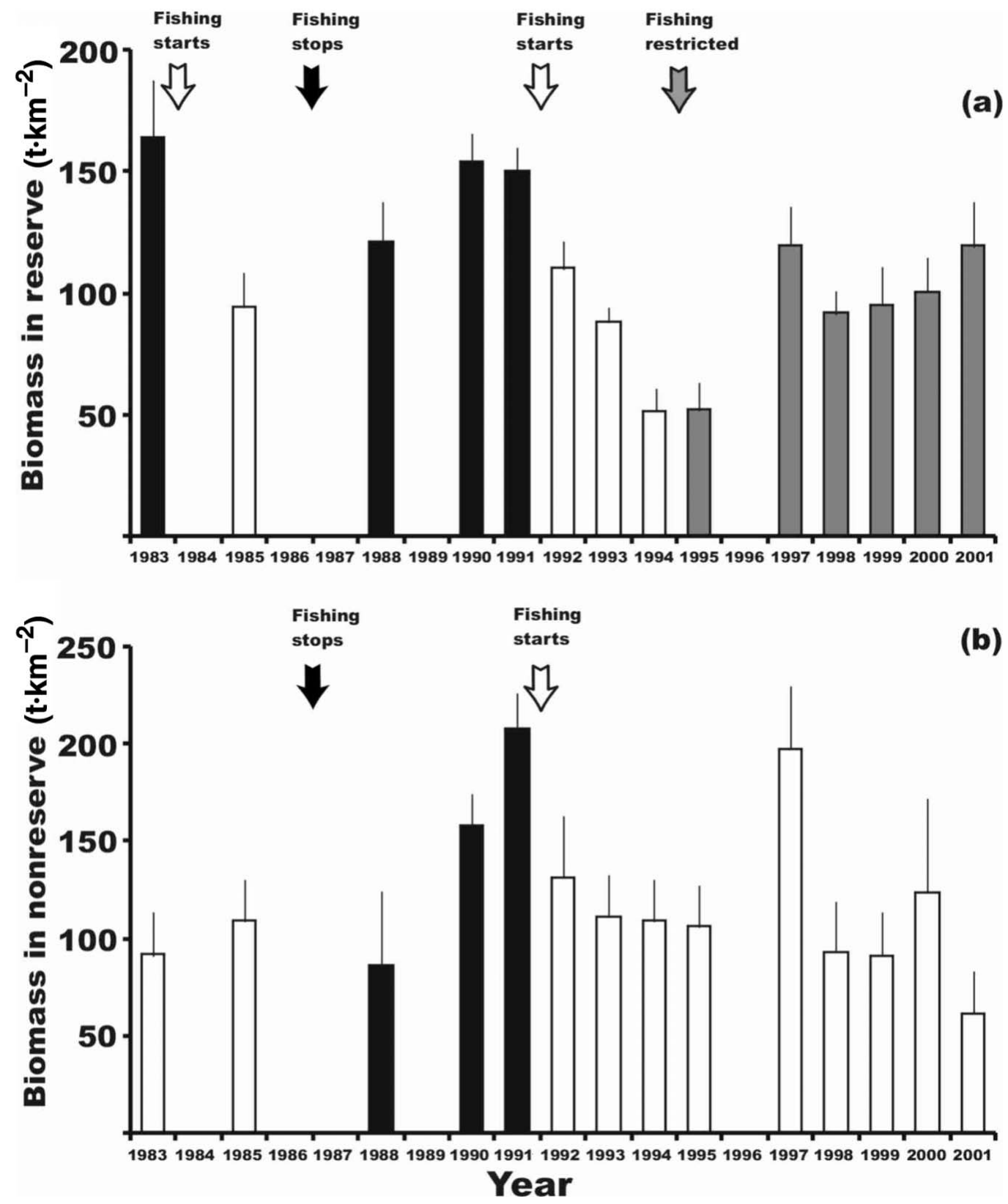

There are several alternative explanations for our results, other than biomass buildup in the reserves influencing the adjacent fishery. A general improvement in environmental conditions could lead to more biomass in the reserves and concomitantly more catch outside them. However, at Apo, we have shown that biomass of some of these targeted fish increased over time outside the reserve close to (within $200 \mathrm{~m}$ ) but not far from the reserve (Russ and Alcala 1996; Russ et al. 2003, 2004). Such a pattern is consistent with spillover rather than a general improvement of the entire reef. Increased biomass in a reserve associated with greater catch outside it could also occur if the fishing effort expands in response to reserve establishment. Overall fishing effort (numbers of fishers and numbers of traps) remained very stable at Sumilon for the study. At Apo, fishing effort of the main fishing gear (hook and line) declined over the study period (Russ et al. 2004). We do concede that the implementation of the marine management plan at Apo in 1986, a plan that banned all forms of destructive fishing gears and fishing by nonresidents, confounds any effects of the reserve alone on the local fishery. This is likely to have led to a general improvement in the reef resources and thus potential catch.

The results presented here are subject to a number of other potential limitations. One limitation was that we restricted the study to just five families of fish at Sumilon and four at Apo. We did this for two reasons. Firstly, these fami- 
Fig. 4. Total annual catch from the nonreserve areas (open columns) and underwater visual census estimates of biomass in the no-take reserves (columns with vertical lines) at (a) Sumilon Island (1979-2001) and (b) Apo Island (1981-2001). Note the differences in vertical scales for catch and reserve biomass. At Sumilon, the annual catch and reserve biomass is for five families that constitute $92 \%$ of the catch at the island (Acanthuridae, Carangidae, Lutjanidae, Lethrinidae, and Caesionidae). Catch at Sumilon is trap and gillnet catch, gears that take $64 \%$ of the catch at the island. At Apo, the annual catch and reserve biomass is for four families that constitute $76 \%$ of catch at the island (same as for Sumilon minus Caesionidae). At Apo, the catch is hook and line, trap, gill net, and spear catch, gears that take $100 \%$ of the catch at the island. Reserve status was no protection (open columns), full no-take protection (solid columns), or partial protection (all gears but line fishing banned) (shaded columns).

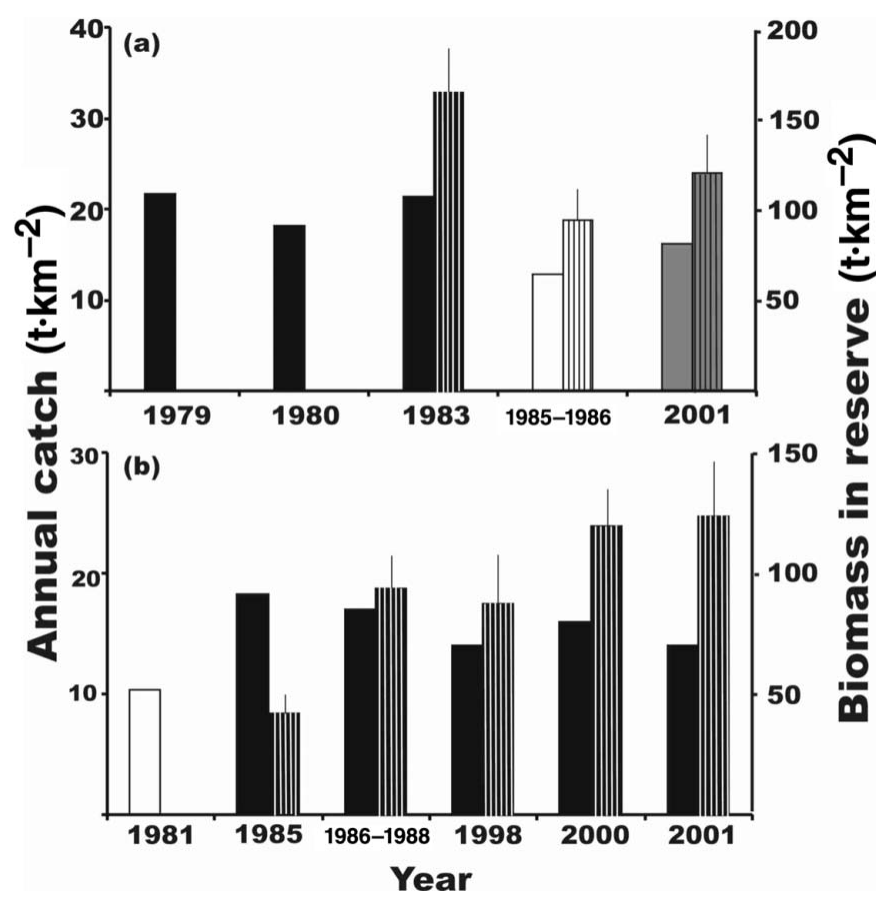

lies constitute the majority of the yield, $92.3 \%$ and $75.6 \%$ by weight, at Sumilon and Apo, respectively. Secondly, they were amenable to underwater visual census, and thus relatively accurate monitoring of abundance inside and outside the reserves was possible. One of these five families was omitted from the Apo analysis (Caesionidae). This family made up only a small proportion of the yield at this island (Maypa et al. 2002). It also displayed a distinct reduction in abundance inside the Apo reserve from 1992 onwards, possibly associated with reduced recruitment, independent of reserve effects (G.R. Russ, unpublished data). We also restricted ourselves to just two fishing gears at Sumilon (traps and gill nets). These were the only two gears for which we had relatively long-term data (1979-2001). They accounted for approximately $64 \%$ of the yield at Sumilon Island. At Apo Island, we had long-term catch data for all of the four main gears (hook and line, traps, gill nets, and spear).

Another limitation of our study was that critical information was often based on a single replicate. Thus, we had only one measurement of reserve biomass and yield at Sumilon after the reserve was fished down in 1985 and only one measurement of these variates after protection was reapplied (2001). At Apo Island, we had only one measurement of yield before reserve establishment. Finally, slight variations in methods used to collect catch data over the period 19832001 may have influenced comparisons of catch over time at each island. Generally, most studies at each island used similar methods and sampled over most of any particular year. However, the one measurement of yield made before reserve establishment at Apo (Alcala and Luchavez 1981) was based on just 49 days of sampling and is thus a less reliable estimate. Such limitations were largely unavoidable.

On the other hand, the study has some unique advantages over the few other studies of the effects of no-take reserves on total fishery yields. Both experiments at Sumilon and Apo have aspects of a before-after-control-impact-pairs experimental design, with before and after data taken at a reserve and fished site at each of two islands. The Sumilon study even incorporated experimental removal and reapplication of reserve status, somewhat analogous to a crossover experimental design encouraged in fisheries experiments (Hilborn and Walters 1992). Our study is also relatively unique in having long-term (18 years) monitoring of fish biomass inside and outside well-protected no-take reserves at two islands coupled with five (Sumilon) and six (Apo) independent measurements of total fishery yield taken over two decades at each island. Clearly, the study takes advantage of two natural experiments that arose from the actions of local fishing communities as opposed to properly designed scientific experiments. Furthermore, while the study is experimental, it relies on correlations between duration of reserve protection and either reserve biomass or local catch. It does not explicitly establish mechanisms by which biomass in reserves may have influenced local catch.

However, in other studies, we have documented one potential mechanism, spillover, to partly explain the neutral to positive results of reserve biomass on catch reported here. At Apo Island, we demonstrated gradual buildup of biomass just outside the southern boundary of the reserve of large predatory fish (Russ and Alcala 1996), Carangidae (jacks) and Acanthuridae (surgeonfish) (Russ et al. 2004), and the large surgeonfish Naso vlamingii (Russ et al. 2003). We have also demonstrated higher hook and line CPUE of Acanthuridae and N. vlamingii closer to (within $200 \mathrm{~m}$ ) than farther from the Apo reserve boundary in 2000-2001 (Russ et al. 2003, 2004). These studies are all consistent with the hypothesis of spillover from the Apo reserve affecting the local fishery in a positive manner. At Sumilon Island, a model incorporating movement rates across the reserve boundary suggested that spillover from the reserve could have increased yield per recruit (and thus total yield) of fusiliers (Caesionidae), the major component of the catch (Russ et al. 1992).

Few other studies have addressed the key question of effects of no-take reserves on total fishery yields. Alcala and Russ (1990) reported a significant reduction in total catch following the breakdown of protection of the Sumilon reserve in the Philippines, a study that forms part of the present research. Russ et al. (2004) showed that the benefits of the reserve to local fisheries for surgeonfish and jacks at 
Apo Island over a 20-year period were higher or sustained catch, increased hook and line CPUE, and a reduction in fishing effort. The fishery and tourism benefits generated by the Apo reserve have enhanced the living standards of the fishing community (Russ et al. 2004).

McClanahan and Kaunda-Arara (1996) and McClanahan and Mangi (2000) reported increased CPUE near the boundary of the Mombasa no-take marine park but a 35\% reduction in total catch when the park removed $65 \%$ of the local fishing area. Thus, the no-take park had a negative effect on total yield but not as much as expected if the reserve simply reduced catch in direct proportion to the fishing area removed. Some positive effects on the fishery, possibly by spillover, likely occurred. In St. Lucia, Roberts et al. (2001) showed that a network of no-take reserves that closed $35 \%$ of local fishing grounds resulted in $46 \%-90 \%$ increases in CPUE after 5 years of reserve protection. These reserves thus had a positive effect on total fishery yield. The Philippine, Kenyan, and St. Lucia studies all measured fish biomass inside and outside reserves, plus adjacent fishery yields, both before and after reserve establishment. Closure to fishing of three large areas of Georges Bank in 1994 increased abundance of scallops (Placopecten magellanicus) substantially (Murawski et al. 2000). Total catch of the scallop fishery increased between 1994 and 1998, despite the reduced fishing area. Fishing effort concentrated outside the boundaries of the closed areas, particularly in places most likely to receive scallop larvae exported from the closed areas (Gell and Roberts 2002). These results suggest that the no-take reserves had a positive effect on total yield of scallops on Georges Bank. Other very good examples of potential spillover from no-take reserves that did not address the question of the reserve effect on total yield directly include those of Kelly et al. (2002) on lobsters in New Zealand and Galal et al. (2002) on reef fish in the Egyptian Red Sea.

The mechanisms by which the reserves in the examples above may have affected fishery yield probably differ. The relatively small spatial scale of the studies in the Philippines, Kenya, and St. Lucia led all of the authors to suggest that spillover of adults was the most likely mechanism affecting yields beyond the boundaries of the reserves. These effects included increased local yields (Sumilon and St. Lucia), a somewhat neutral effect on yield (Apo), or decreased yield but not decreased as much as expected based on the amount of fishing area removed (Mombasa). The increased total yield of scallops on Georges Bank following establishment of no-take areas is most likely due to the recruitment effect. Until recently, it was assumed that any positive influences of reserves on local CPUE and yields were due to adult spillover. Recent studies of the potential for limited larval dispersal and "self-recruitment" (e.g., Jones et al. 1999; Swearer et al. 1999; James et al. 2002) have led to the possibility that reserves may affect local fishery yields by both spillover and the recruitment effect (Gell and Roberts 2002).

In conclusion, our study has demonstrated that closure of $10 \%-25 \%$ of available fishing area of two small islands in the Philippines resulted in sustained, or even enhanced, total catch of the local fishery in the long term. The result challenges the frequent suggestion that no-take reserves will result in reduced total catch. The latter may occur in the short term. But if targeted fish biomass builds up substantially in- side no-take reserves, the potential for them to sustain, or even enhance, fishery yields by spillover or enhanced recruitment into fished areas is very real.

\section{Acknowledgements}

This project was partially funded by the United Nations Environment Program (1983), the Great Barrier Reef Marine Park Authority (1985), and Pew Fellowships in Marine Conservation to A.C.C. and G.R.R.

\section{References}

Alcala, A.C. 1981. Fish yields of coral reefs of Sumilon Island, central Philippines. Natl. Res. Counc. Philipp. Res. Bull. 36: 1-7.

Alcala, A.C., and Luchavez, T. 1981. Fish yield of the coral reef surrounding Apo Island, central Visayas, Philippines. Proc. 4th Int. Coral Reef Symp. 1: 69-73.

Alcala, A.C., and Russ, G.R. 1990. A direct test of the effects of protective management on abundance and yield of tropical marine resources. J. Cons. Int. Explor. Mer, 47: 40-47.

Allison, G.W., Lubchenco, J., and Carr, M.H. 1998. Marine reserves are necessary but not sufficient for marine conservation. Ecol. Appl. 8(Suppl.): S79-S92.

Bellwood, D.R. 1988. Seasonal changes in the size and composition of the fish yield from reefs around Apo Island, central Philippines, with notes on methods of yield estimation. J. Fish Biol. 32: $881-893$.

Dayton, P.K., Sala, E., Tegner, M.J., and Thrush, S.F. 2000. Marine protected areas: parks, baselines, and fishery enhancement. Bull. Mar. Sci. 66: 617-634.

Froese, R., and Pauly, D. 1997. Fishbase 97: concept, design and data sources. International Center for Living Aquatic Resources Management, Manila, Philippines.

Gaines, S.D., Gaylord, B., and Largier, J.L. 2003. Avoiding current oversights in marine reserve design. Ecol. Appl. 13(Suppl.): S32-S46.

Galal, N., Ormond, R.F.G., and Hassan, O. 2002. Effect of a network of no-take reserves in increasing catch per unit effort and stocks of exploited reef fish at Nabq, South Sinai, Egypt. Mar. Freshw. Res. 53: 199-205.

Gell, F.R., and Roberts, C.M. 2002. The fishery effects of marine reserves and fishery closures. WWF-US, Washington, D.C.

Gerber, L.R., Botsford, L.W., Hastings, A., Possingham, H.P., Gaines, S.D., Palumbi, S.R., and Andelman, S. 2003. Population models and marine reserve design: a retrospective and prospective synthesis. Ecol. Appl. 13: S47-S64.

Hilborn, R., and Walters, C.J. 1992. Quantitative fisheries stock assessment. Choice, dynamics and uncertainty. Chapman and Hall, New York and London.

Jackson, J.B.C., Kirby, M.X., Berger, W.H., Bjorndal, K.A., Botsford, L.W., Bourque, B.J., Bradbury, R.H., Cooke, R., Erlandson, J., Estes, J.A., Hughes, T.P., Kidwell, S., Lange, C.B., Lenihan, H.S., Pandolfi, J.M., Peterson, C.H., Steneck, R.S., Tegner, M.J., and Warner, R.R. 2001. Historical overfishing and the recent collapse of coastal ecosystems. Science (Wash., D.C.), 293: 629-638.

James, M.K., Armsworth, P.R., Mason, L.B., and Bode, L. 2002. The structure of reef fish metapopulations: modelling larval dispersal and retention patterns. Proc. R. Soc. Lond. B Biol. Sci. 269: 2079-2086.

Jones, G.P., Milicich, M.I., Emslie, M., and Lunow, C. 1999. Selfrecruitment in a coral reef fish population. Nature (Lond.), 402: 802-804. 
Kelly, S.D., Scott, D., and MacDiarmid, A.B. 2002. The value of a spillover fishery for spiny lobsters around a marine reserve in northern New Zealand. Coastal Manag. 30: 153-166.

Maypa, A.P., Russ, G.R., Alcala, A.C., and Calumpong, H.P. 2002. Long-term trends in yield and catch rates of the coral reef fishery at Apo Island, central Philippines. Mar. Freshw. Res. 53: 207-213.

McClanahan, T.R., and Kaunda-Arara, B. 1996. Fishery recovery in a coral-reef marine park and its effect on the adjacent fishery. Conserv. Biol. 10: 1187-1199.

McClanahan, T.R., and Mangi, S. 2000. Spillover of exploitable fishes from a marine park and its effect on the adjacent fishery. Ecol. Appl. 10: 1792-1805.

Murawski, S.A., Brown, R., Lai, H.L., Rago, P.J., and Hendrickson, L. 2000. Large-scale closed areas as a fisherymanagement tool in temperate marine systems: the Georges Bank experience. Bull. Mar. Sci. 66: 775-798.

Palumbi, S.R. 2001. The ecology of marine protected areas. In Marine community ecology. Edited by M.D. Bertness, S.D. Gaines, and M.E. Hay. Sinauer, Sunderland, Mass. pp. 509-530.

Pauly, D., Christensen, V., Dalsgaard, J., Froese, R., and. Torres, F. 1998. Fishing down food webs. Science (Wash., D.C.), 279: 860-863.

Rakitin, A., and Kramer, D.L. 1996. Effect of a marine reserve on the distribution of coral reef fishes in Barbados. Mar. Ecol. Prog. Ser. 131: 97-113.

Roberts, C.M., and Hawkins, J.P. 2000 Fully-protected marine reserves: a guide. WWF Endangered Seas Campaign, Washington, D.C.

Roberts, C.M., Bohnsack, J.A., Gell, F., Hawkins, J.P., and Goodridge, R. 2001. Effects of marine reserves on adjacent fisheries. Science (Wash., D.C.), 294: 1920-1923.

Russ, G.R. 2002. Yet another review of marine reserves as reef fisheries management tools In Coral reef fishes: dynamics and diversity in a complex ecosystem. Edited by P.F. Sale. Academic Press, San Diego, Calif. pp. 421-443.
Russ, G.R., and Alcala, A.C. 1996. Do marine reserves export adult fish biomass? Evidence from Apo Island, central Philippines. Mar. Ecol. Prog. Ser. 132: 1-9.

Russ, G.R., and Alcala, A.C. 1998. Natural fishing experiments in marine reserves 1983-1993: roles of life history and fishing intensity in family responses. Coral Reefs, 17: 399-416.

Russ, G.R., and Alcala, A.C. 1999. Management histories of Sumilon and Apo marine reserves, Philippines, and their influence on national marine resource policy. Coral Reefs, 18: 307319.

Russ, G.R., Alcala, A.C., and Cabanban, A.S. 1992. Marine reserves and fisheries management on coral reefs with preliminary modeling of the effects on yield per recruit. Proc. 7th Int. Coral Reef Symp. 2: 988-995.

Russ, G.R., Alcala, A.C., and Maypa, A.P. 2003. Spillover from marine reserves: the case of Naso vlamingii at Apo Island, Philippines. Mar. Ecol. Prog. Ser. 264: 15-20.

Russ, G.R., Alcala, A.C., Maypa, A.P., Calumpong, H.P., and White, A.T. 2004. Marine reserve benefits local fisheries. Ecol. Appl. 14: 597-606.

Statsoft, Inc. 1995. Statistica. Vol. 1. General conventions and statistics I. Statsoft, Inc., Tulsa, Okla.

Swearer, S.E., Caselle, J.E., Lea, D.W., and Warner, R.R. 1999. Larval retention and recruitment in an island population. Nature (Lond.), 402: 799-802.

Underwood, A.J. 1981. Techniques of analysis of variance in experimental marine biology and ecology. Oceanogr. Mar. Biol. Annu. Rev. 19: 513-605.

White, A.T., and Savina, G.C. 1987. Reef fish yield and non-reef catch of Apo Island, Negros, Philippines. Asian Mar. Biol. 4: $67-76$.

White, A.T., Courtney, C.A., and Salamanca, A. 2002. Experience with marine protected area planning and management in the Philippines. Coastal Manag. 30: 1-26. 